\title{
Landslide scar/soil erodibility mapping using Landsat TM/ETM+ bands 7 and 3 Normalised Difference Index: a case study of central region of Kenya
}

\author{
Mwaniki W. Mercy, ${ }^{\mathrm{a}, \text {, }}$, Agutu O. Nathan ${ }^{\mathrm{b}, \mathrm{d}}$, Mbaka G. John ${ }^{\mathrm{c}}$, Ngigi G. Thomas ${ }^{\mathrm{d}}$, and \\ Waithaka H. Edward ${ }^{d}$ \\ ${ }^{a}$ Bamberg University, Berlin, Germany. mercimwaniki@yahoo.com \\ ${ }^{\mathrm{b}}$ Curtin University Perth, Australia. nathanagutu01@gmail.com \\ ${ }^{\mathrm{c}}$ University of Koblenz and Landau, Germany. mbakagichimu@ gmail.com \\ d Jomo Kenyatta University of Agriculture and Technology, Department of Geomatic \\ Engineering and Geospatial Information Systems, P.O. Box 62000-00200 Nairobi, Kenya. \\ tgngigi@jkuat.ac.ke, hunja@eng.jkuat.ac.ke \\ *Corresponding author e-mail address: mercimwaniki@yahoo.com
}

\begin{abstract}
Landsat series multispectral remote sensing imagery has gained increasing attention in providing solutions to environmental problems such as land degradation which exacerbate soil erosion and landslide disasters in the case of rainfall events. Multispectral data has facilitated the mapping of soils, land-cover and structural geology, all of which are factors affecting landslide occurrence. The main aim of this research was to develop a methodology to visualize and map past landslides as well as identify land degradation effects through soil erosion and land-use using remote sensing techniques in the central region of Kenya. The study area has rugged terrain and rainfall has been the main source of landslide trigger. The methodology comprised visualizing landslide scars using a False Colour Composite (FCC) and mapping soil erodibility using FCC components applying expert based classification. The components of the FCC were: the first independent component (IC1), Principal Component (PC) with most geological information, and a Normalised Difference Index (NDI) involving Landsat TM/ETM+ band 7 and 3.
\end{abstract}

The FCC components formed the inputs for knowledge-based classification with the following 13 classes: runoff, extreme erosions, other erosions, landslide areas, highly erodible, stable, exposed volcanic rocks, agriculture, green forest, new forest regrowth areas, clear, turbid and salty water. Validation of the mapped landslide areas with field GPS locations of landslide affected areas showed that $66 \%$ of the points coincided well with landslide areas mapped in the year 2000. The classification maps showed landslide areas on the steep ridge faces, other erosions in agricultural areas, highly erodible zones being already 
weathered rocks, while runoff were mainly fluvial deposits. Thus, landuse and rainfall processes play a major role in inducing landslides in the study area.

Keywords: Landslide scar, Soil erodibility mapping, Principal Component Analysis (PCA), False colour Composite (FCC), Independent Component analysis (ICA), Normalised difference Index (NDI), Normalised Difference Mid Red (NDMIDR) index

\section{Introduction}

Increased availability of multitemporal remote sensing data has facilitated enviromental studies. Of immense benefit has been land degradation which include; landslides, flooding, soil erosion, desertification, deforestation, soil salinity, and poor agricultural practices. Land degradation leads to decreased productivity of the land and is not uniform even on the same landscape. Remote sensing methods provide a cost effective means to the management of land degradation whereas direct field methods are expensive and time consuming (Mumby et al., 1999). Therefore, remote sensing techniques are increasingly being used for mapping and identifying land degradation risks and modeling soil loss processes due to the advances in image processing which enhances features, discriminating the surrounding areas through spectral characteristics (Baroudy, 2011; Baroudy and Moghanm, 2014; Lu et al., 2007; Metternicht et al., 2010).

Landslides and soil weathering are part of geomorphic surface processes which affect terrain at varying climatic conditions causing population displacement and negative effects on the natural environment (Alimohammadlou et al., 2013). Information on past landslide occurrences do exist in form of detailed inventories and hazard maps while in landslide prone areas where no such information exists, the inhabitants are exposed to the risk of unstable slopes (Taherynia et al., 2014). Future landslide hazards have high probability of recurring under similar trigger conditions, thus it is important to map past landslides, conditions, and or processes that promote instability in order to predict and estimate future occurrences (Guzzetti 
et al., 2012). However, landslides can occur in areas with no history of landslide activities due to human activities, changes in topography, and or hydrologic conditions (Highland and Bobrowsky, 2008). Mapping landslide affected and soil eroded areas is therefore a safety precaution measure (Lee and Pradhan, 2006), and also aid efficient utilization of land based resources hence improved productivity of land resources.

Soils are continuously evolving from rocks through weathering processes under the influence of environmental conditions such as: weather, climate, topography, vegetation, and human activity. Therefore, weathering processes are not only important for soils creation, but also determine soil properties, fertility, and slope stability (Robinson and Moses, 2011). Soils are classified by remote sensors based on their properties e.g. roughness, colour, texture, moisture and organic matter content (Campbell, 2009), which are acquired from the geologic properties of the parent rock material. Chen and Campagna (2009) notes that the future of Remote sensing applications in geology will involve: higher spectral resolution, finer band width, higher resolution DEM as well as improvements in enhancements and classification methods. Gao and Liu (2008) investigated the role of spatial and spectral resolution in mapping land degradation by comparing the performance of Landsat ETM+ and ASTER data. They found that the spectral resolution of an image is not as important as the information content present in each band i.e. Landsat ETM+ outperformed ASTER data due to the highly repetitive spectral content of ASTER's six shortwave infrared bands.

Most often conditions under which previous landslides occurred are necessary in order to differentiate landslide scars from old mining areas, or burnt landscape (Alkhasawneh et al., 2013). The main aim of this research was to develop a methodology to visualize and map past shallow landslides as well as identify land degradation effects through soil erosion and landuse. The proposed methodology is expected to enhance identification of landslide scar and deposition areas, and therefore lead to their classification, while considering other land 
covers. The study area has in the past experienced landslides triggered mainly by extreme rainfall events (Mwaniki et al., 2011; Ngecu and Mathu, 1999) and problems associated with high population pressure further exacerbate the problem (Dewitte et al., 2012; Westerberg and Christiansson, 1998). The remainder of the study is organised as follows: in section 2, a review of the remote sensing techniques for mapping soil erodibility and landslides is given; section 3 describes the study area, dataset and the methodology adopted for the study; results and discussions are presented in section 4 and the study is concluded in section 5 .

\section{Remote sensing in soil erodibility and landslide mapping}

Soil erodibility is the susceptibility of soil to agents of erosion, these agents are interactions of several factors including: soil properties (texture, cohesion, roughness, organic matter content, and moisture), rainfall, topography (slope length and steepness), and land-use (Lal, 2001; Wang et al., 2003). Advances in both microwave and optical remote sensing have enabled mapping of the above factors to high accuracies and at multi-temporal basis boosting change detection quantification. The integration of the commonly used soil loss and sediment yield models, Revised / Universal Soil Loss Equation (R/USLE) (e.g. Arekhi et al., 2012; Bhandari et al., 2015; Meusburger et al., 2010), Soil and water assessment tool (SWAT) model (e.g. Wang et al., 2015) or G2 model (Panagos et al., 2012) to remote sensing data in GIS platform have boosted watershed management (e.g. Moreno-Madriñán et al., 2015; Mutekanga et al., 2010), water quality investigations (e.g. Kim et al., 2014), shallow and rapid landslide mapping (e.g. Kim et al., 2005; Pradhan et al., 2012), and soil property analysis for applications in agriculture (Blasch et al., 2015). The C-factor in the R/USLE soil loss models has been predicted with success using vegetation indices, band ratios or land use classification. For example, Wang et al. (2002) used band ratio $(T M 3+T M 7) / T M 4$ to estimate spatial variability of the C-factor and the result had the lowest RMSE value among other geo-statistical methods of assigning C-factor values. Yang (2014) used fraction cover 
instead of NDVI to estimate the C-factor and consequently to assess hillslope erosion hazard, sediment and water quality after a severe bushfire.

Singh et al. (2004) developed an empirical linear relationship between NDVI and soil colour which could be used to predict soil erosion process by examining topsoil characteristics, which influence soil surface colour. The gradual uncovering of soil-top surface by erosion can result in detectable spectral changes due to changes in organic matter content, compaction levels, roughness, iron oxides and other soil minerals (Vrieling, 2006). Thus, soil surface state can be related to runoff and erosion processes. The difficulty of measuring soil's reflectance using satellite data has been overcome using such techniques as Tasseled Cap Transformation (TCT) (e.g. Sajadi, 2011; Vorovencii, 2007), and linear spectral unmixing (e.g. Zhang et al., 2014), thus enabling soil erosion status assessment using multi-temporal multi-spectral data such as Landsat series. Guerschman et al. (2015) assessed soil properties using spectral unmixing of non/photosynthetic vegetation and bare soil fractions from Landsat and MODIS data. It was found that spectral unmixing models are insensitive to soil colour and soil moisture in the top soil layer (few centimetres) which influences surface reflectance.

Soil erosion and unstable areas associated with deposition can be detected on SAR images using temporal interferometric decorrelation (i.e. coherence is high when land surface characteristics on two dates are similar), although vegetation and soil moisture changes can also be a source of decorrelation (Vrieling, 2006). Barrett et al. (2009) reviewed methods used to map and monitor soil moisture changes under various topographic and land-cover conditions using active microwave remote sensing enabling erosion detection even in humid regions. Vrieling, (2006) reported the need to integrate coherence imagery with additional spatial data (e.g. optical satellite imagery) due to several causes of temporal decorrelation. With the advances in high resolution satellite imagery, the mapping and monitoring of linear erosion features through automated extraction algorithms for gully identification have been 
developed (e.g. Desprats et al., 2013; Shruthi et al., 2011). The use of multi-temporal DEMs using SAR interferometry provides the possibility to assess erosion and deposition volumes for both landslides (Liao et al., 2012; Rott and Nagler, 2006; Tsutsui et al., 2007) and erosion studies (e.g. Baade and Schmullius, 2010; Smith et al., 2000); in other words the subtraction of a post event DEM from pre-event DEM.

Landslides are localized phenomena that reflect site specific stability conditions where vegetation cover contributes to root cohesion, and thus influences slope stability (Roering et al., 2003; Schmidt et al., 2001). Thus, applications involving landsliding or risk mapping require the identification of disturbed vegetation or land degradation, which are then related to landslide incidences. Land degradation monitoring has been evaluated through land-use landcover change detection analysis (e.g. El Baroudy, 2011; Gao and Liu, 2010; Lu et al., 2007; Metternicht et al., 2010) and vegetation spectral indices (Govender et al., 2007). For example, Dhakal et al. ( 2002) compared the robustness of four change detection techniques namely: Spectral image difference (SID), PCA, Spectral change vector analysis (SCVA), and Tasseled cap Brightness Image difference (TCBID) to map erosion and flooded areas after a rainfall event using multi-temporal Landsat TM imagery. In general visible bands were found to be effective while the change image produced by spectral change vector analysis had the highest accuracy.

Vegetation spectral indices take the form of band ratios or Normalized Difference Index (NDI, equation 1) such as: Normalized Burn Ratio (NBR), Normalised Difference Vegetation Index (NDVI), and Physiological reflectance Index (PRI). For example, Meyer et al. (2001) sort to relate how fire and storm events acceleralated soil erosion and shallow landsliding in Idaho batholith. Epting et al. (2005) developed burn severerity index but only for forested sites while, Ceccato et al. (2002) noted that the amount of fuel moisture influences burning efficiency. 


$$
N D I=\frac{\lambda_{i}-\lambda_{j}}{\lambda_{i}+\lambda_{j}}
$$

Where: $\lambda$ is the refrectance in the $i$ and $j$ spectral regions. NDVI is a useful indicator of green biomass, although it has limitations in that it responds to both vegetation greeness and soil reflectance as discussed by several authors (e.g. Ardavan et al., 2012; Glenn et al., 2008; Govaerts and Verhulst, 2010; Mašková et al., 2008). PRI is a water stress index for assessing plant-water status (Garbulsky et al., 2011; Thenot et al., 2002) and is very sensitive to soil reflectance in vegetated areas, making it more useful in areas with dense vegetation and dark soils. Sims and Gamon (2002) showed PRI as an indicator of vegetation stress while Bright et al. (2010) used it as an indicator of vegetation disturbance.

Other spectral indices to improve on NDVI have been developed such as: Soil Adjusted Vegetation Index (SAVI), its improved versions such as Modified / Transformed Soil Adjusted Vegetation Index (M)/(T)SAVI (e.g. Purevdorj et al., 1998), Soil and Atmospherically Resistant Vegetation Index (SARVI) (Bright et al., 2010; Jensen, 2007) and Soil Adjusted Crop Residue Index (SACRI) improved by Bonn et al. (1996) using SWIR and NIR bands. Hochschild et al. (2003) showed that negative TSAVI values corresponded to potentially degraded areas while Sajadi (2011) compared NDVI to Tasselled cap greenness and brightness in a vegetation classification, where it was found that high NDVI values overlapped with areas of high greenness, low NDVI areas overlapped with areas of high wetness and moderate NDVI areas overlapped with areas of high brightness.

Landsat imagery has found major applications in developing spectral indices, especially the SWIR bands which have successfully distinguished crop residue from soils (e.g. Daughtry et al., 2004; Nagler et al., 2000) therefore making Landsat series more appropriate than SPOT High Resolution Visible (HRV) in detecting dry or non-photosynthetic vegetation. Vohora and Donoghue (2004) developed Normalised Difference Mid Infrared spectral index (NDMIDIR, equation 2) using Landsat bands 7 and 4 to map areas of disturbed vegetation 
174 (including stressed forests or forest fires), which successfully identified landslide scars and

175 forest fire scars compared to NDVI, which only depicted areas with healthy vegetation.

$$
N D M I D I R=\frac{T M 4-T M 7}{T M 4+T M 7}
$$

176

where TM is Landsat Thermal Mapper band. Deng et al. (2015) developed a Ratio Normalized Difference Soil Index (RNDSI), an empirical approach to enhance soil information from vegetation and impervious surface areas. The RNDSI was developed by dividing a normalized difference soil index of Landsat's bands 7 and 2 by the first tasseled cap transform (brightness, measure of soil). Nield et al. (2007) developed a normalised difference ratio using Landsat ETM+ bands 5 and 7 to map gypsum and sodium affected soils. Other spectral indices such as PRI and Normalised Difference Water Index (NDWI) may be enhanced with more narrower spectral bands such as Landsat 8, Operational Land Imager (OLI) or hyperspectral imagery. NDWI (equation 3) is implemeted using two near infrared channels centred around $0.86 \mu \mathrm{m}$ and $1.24 \mu \mathrm{m}$, while PRI (equation4) uses bands centred around $0.531 \mu \mathrm{m}$ and $0.570 \mu \mathrm{m}$ as in equations 3 and 4 , respectively. Such indices found more applications in precise agriculture and forestry for stress detection, monitoring and management of pests and diseases. Xu (2006) enhanced open water features more sufficiently and eliminated built up noise by modifing the NDWI, where near infrared band was replaced by a mid infrared band.

$$
N D W I=\frac{\lambda_{0.86}-\lambda_{1.24}}{\lambda_{0.86}+\lambda_{1.24}} \quad \text { (3) } \quad P R I=\frac{\lambda_{0.531}-\lambda_{0.570}}{\lambda_{0.531}+\lambda_{0.570}}
$$

Digital image processing and enhancements (such as False Colour Combinations, FCC, involving processed images or multispectral data) provide a powerful means of visualizing landslide features. For example, Mondini et al. (2011) used an FCC comprising (סNDVI, IC4, PC4) to visualise landslide areas triggered by typhoons while Fernández et al. (2008) used several FCCs comprising bands from the visible, NIR, and SWIR regions to show landslide 
scars and lithological changes related to landslides. Whitworth et al. (2005) used FCC image enhancement, using airborne photography imagery and investigated the effect of texture enhancement in indentifying landslides, where the classification successfully differentiated landslide areas from stable slopes. Ramli et al. (2010) has reviewed other lineament visualization methods useful to landslide hazard assessment.

Jensen et al. (2009) discussed various classification methods (such as ANN, decision trees, machine learning, maximum likelihood, object oriented classification, support vector machines, spectral mixture analysis) and recommended the use of ancillary data in classifications in order to improve classification accuracy. Ancillary data may be in the form of environmental data (e.g. slope, elevation) or processed image bands (e.g. band ratios, spectral indices). For example, Mwaniki et al. (2015) used band ratios of Landsat ETM+ data in an expert based classification and successfully mapped the geology of the current study area whereas, Alatorre and Beguería (2009) used DTM orientation to explore morphology of active areas of erosion and areas at risk, since hill side aspect is a determinant of weathering rate as noted by Nadal-Romero et al. (2007).

In addition, feature extraction, data reduction or transformation greatly improves classification accuracy (e.g. Chang and Wang, 2006) and eases separability of the features such that the few chosen components characterize patterns which maximize separability without degrading the performance of the resulting classifier (Zhang and Zhong, 2009). Such feature space tranforms methods include; Minimum Noise Fraction (MNF), tassel cap, PCA, and ICA. PCA techniques as an image enhancement method has also been used in landslide mapping (e.g. Petley et al., 2002; Rawashdeh et al., 2006).

This research has modified NDMIDIR spectral index developed by Vohora and Donoghue, (2004) to Normalised Difference Mid Red index (NDMIDR, equation 5) for Landsat TM/ETM+ and NDMIDIR (equation 6) for Landsat OLI. These have been used in a FCC 
involving independent and principal component as the basis of landslide mapping. The modification was informed by the reflectance response of various terrain features (Campbell, 1996) where, Landsat TM bands 2 and 4 are high reflective zones for vegetation, band 3 is helpful for discriminating soil from vegetation due to the high absorbency effect of vegetation. Bands 5 and 7 are best suited for rock and soil studies since soil has high absorption in band 7 and high reflectance in band 5 .

$$
N D M I D R=\frac{T M 7-T M 3}{T M 7+T M 3} \quad \text { (5) } \quad N D M I D I R=\frac{T M 7-T M 4}{T M 7+T M 4}
$$

A methodology which could enhance identification of landslide scars and depositional areas and therefore lead to their classification was developed.

\section{Methodology}

\subsection{Study area}

The study area covers the central highlands of Kenya, extending from longitude $35^{\circ} 34^{\prime} 00^{\prime \prime} \mathrm{E}$ to $38^{\circ} 15^{\prime} 00^{\prime \prime} \mathrm{E}$ and latitudes $0^{\circ} 53^{\prime} 00^{\prime \prime} \mathrm{N}$ to $2^{\circ} 10^{\prime} 00^{\prime \prime} \mathrm{S}$ (Figure 1 ). The area covers rugged mountainous terrain, with deep incised river valleys and narrow ridges in the highland regions to low lying gently slopes and plains in the marginal areas, and altitude varying from $450 \mathrm{~m}$ to $5150 \mathrm{~m}$ above mean sea level. Deep weathering of rocks is attributed to soil formation, with three major types; nitosols, andosols and cambisol (Ngecu et al., 2004). The climate of the region varies from highland to savannah with predominant land-use land-covers being: forest, settlement, and agriculture. Landslides triggered by rainfall are also a major threat on the south eastern slopes of Aberdare mountain ranges (e.g. Kipseba et al., 2013; Maina-Gichaba et al., 2013; Mwaniki et al., 2011; Ogallo et al., 2006), Machakos county (Ogora and Kotut, 2013) and Baringo and Marakwet districts in the Rift valley (Kipchumba, 2011; Kipkiror and Towett, 2013; Maina-Gichaba et al., 2013). 


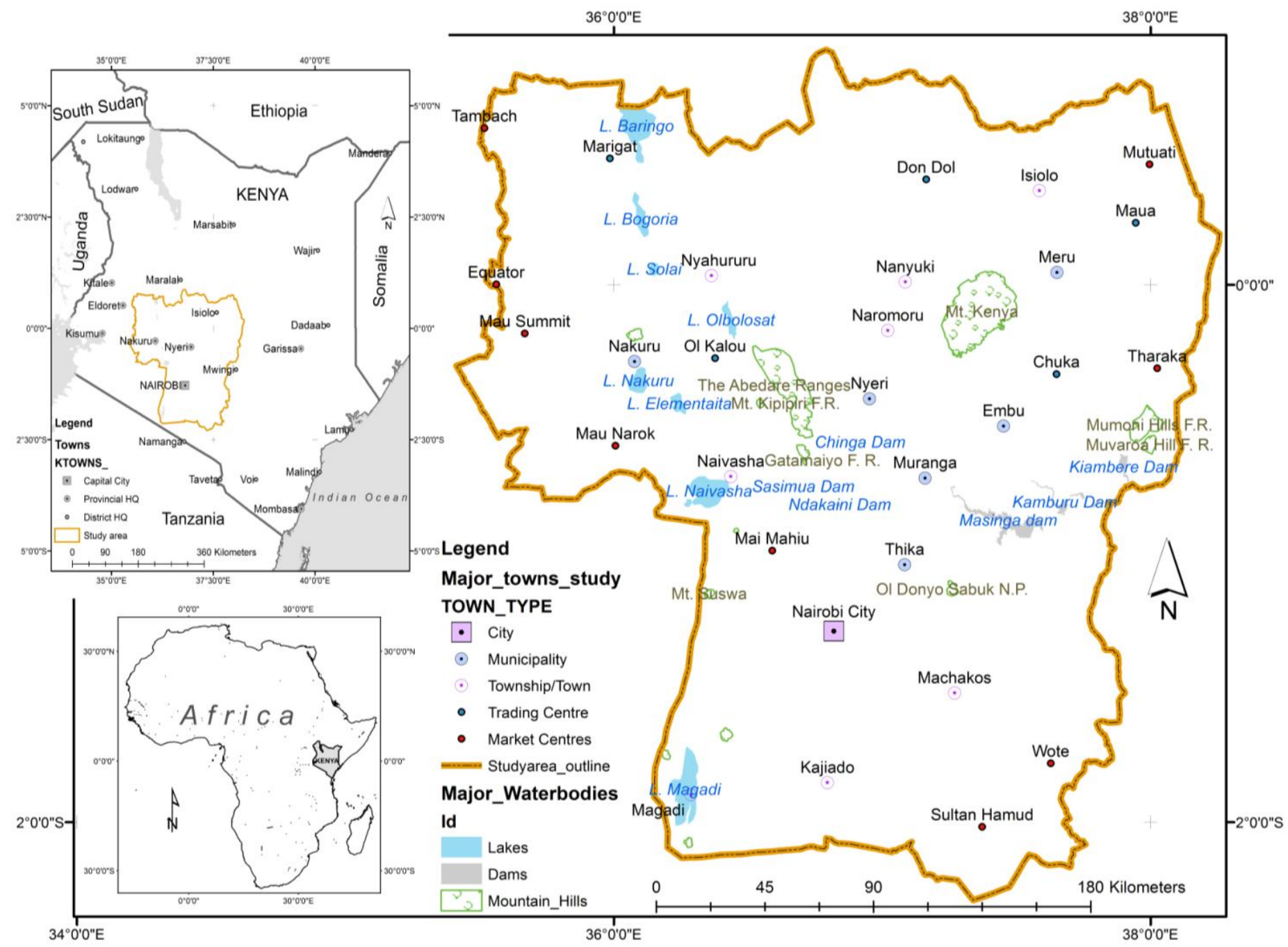

Figure 1: Map of the Study Area

\subsection{Data description}

245 Landsat ETM+ (year 2000) and Landsat TM (year 1995), Level 1T, geometrically corrected

246 and orthorectified, scenes p168r060, p168r061 and p169r060 near free cloud cover, were

247 downloaded from USGS web page and pre-processed individually for each year by layer

248 stacking. Atmospheric correction was not necessary for images taken on the same calendar

249 date (Song et al., 2001) i.e. path 168, however it was found necessary before mosaicing path

250168 and 169 into a single image since there was a difference of three weeks in acquisition

251 date, although the season was the same. Subsetting was then done to reduce the image to the 
area of interest and also help increase processing speed by eliminating extraneous data in the file.

\subsection{Image enhancement}

Image enhancement involved first the application of a standardized covariance PCA in order to enable factor loading, which further facilitated the choice of PCs containing most soil or geologic information. From table 1 and 2, all information contained in PC1 is positively correlated, making it difficult for separation, although PC1 had the highest contribution from bands 5 and 7 which contained soil and geology information. PC2 had the highest contribution of information from band 4 , which is basically a vegetation band, while PC3 had the little information from band 7. Both PC4 and PC5 in Landsat 5 were suited for the FCC, but PC4 was choosen given that it had slightly higher variance value compared to PC5 and also that lineaments were more enhanced by visual comparison of the two. However, with Landsat 7, PC5 had better enhanced lineaments than PC4, although PC5 had lower variance than PC4. This was due to the higher contribution from band 3 in PC5 for Landsat 7, and similarly in PC4 for Landsat 5. PC7 was disqualified on the basis of least contribution from all bands except bands 1 and 2 which mainly contain water information. Further, independent component analysis was performed to enhance geology feature distinction which was achieved at IC1. IC1 and PC4 in Landsat 5, and IC1 and PC5 for Landsat 7 were therefore the red and green channels of the FCC. 
Table 1: PC Factor Loading computed from covariance matrix, Landsat 5, year 1995

\begin{tabular}{|l|l|l|l|l|l|l|}
\hline & PC1 & PC2 & PC3 & PC4 & PC5 & PC7 \\
\hline Eigvec.1 & 0.3913679 & -0.1997434 & 0.6898554 & 0.4923813 & -0.1824007 & -0.2352102 \\
\hline Eigvec.2 & 0.2011322 & -0.0477641 & 0.2942073 & -0.0936230 & 0.1659178 & 0.9134617 \\
\hline Eigvec. 3 & 0.2494026 & 0.1856118 & 0.3787109 & -0.6143128 & 0.5258252 & -0.3256570 \\
\hline Eigvec.4 & 0.4257289 & -0.7803997 & -0.2869511 & -0.3269640 & -0.1335867 & -0.0513726 \\
\hline Eigvec.5 & 0.6754827 & 0.3364313 & -0.4593930 & 0.3552763 & 0.3053992 & -0.0022376 \\
\hline Eigvec.7 & 0.3265784 & 0.4485083 & 0.0271368 & -0.3718710 & -0.7426940 & 0.0395896 \\
\hline \% Var & 94.4929 & 3.8241 & 1.3270 & 0.2083 & 0.1304 & 0.0173 \\
\hline
\end{tabular}

Table 2: PC Factor Loading computed from covariance matrix, Landsat 7, year 2000

\begin{tabular}{|l|l|l|l|l|l|l|}
\hline & PC1 & PC2 & PC3 & PC4 & PC5 & PC7 \\
\hline Eigvec.1 & 0.3504299 & 0.1499419 & 0.3435107 & -0.066525 & 0.4175276 & -0.7469684 \\
\hline Eigvec.2 & 0.3118657 & 0.1777410 & 0.4125140 & -0.095809 & 0.5037826 & 0.6618187 \\
\hline Eigvec.3 & 0.4063747 & -0.1377272 & 0.5463604 & 0.3519655 & -0.6264414 & 0.0327518 \\
\hline Eigvec.4 & 0.2829485 & 0.8287152 & -0.2396491 & -0.241326 & -0.3422539 & 0.0190695 \\
\hline Eigvec.5 & 0.5846698 & -0.1363933 & -0.5776030 & 0.5147799 & 0.1971126 & 0.0456196 \\
\hline Eigvec.7 & 0.4392034 & -0.4707280 & -0.1492179 & -0.734356 & -0.1531462 & 0.0227320 \\
\hline \% Var & 96.64 & 1.91 & 1.18 & 0.17 & 0.08 & 0.02 \\
\hline
\end{tabular}

271 The third FCC component was a spectral index which could enhance devegetated and

272 landslide scars. For this purpose, NDVI was compared to a new NDMIDR index (equation 5),

273 where it was found that NDVI only emphasized vegetated areas whereas NDMIDR

274 emphasized geological features and had improved texture. Fernández et al. (2008)

275 recommended the combination of textural analysis and digital classification in order to

276 indentify landslide features or mobilized areas. Therefore, NDMIDR spectral index provided

277 some textural characteristics as seen in the figure 2, whereas the FCC incorporating IC1, PC5

278 and NDMIDR is shown in figure 3. 

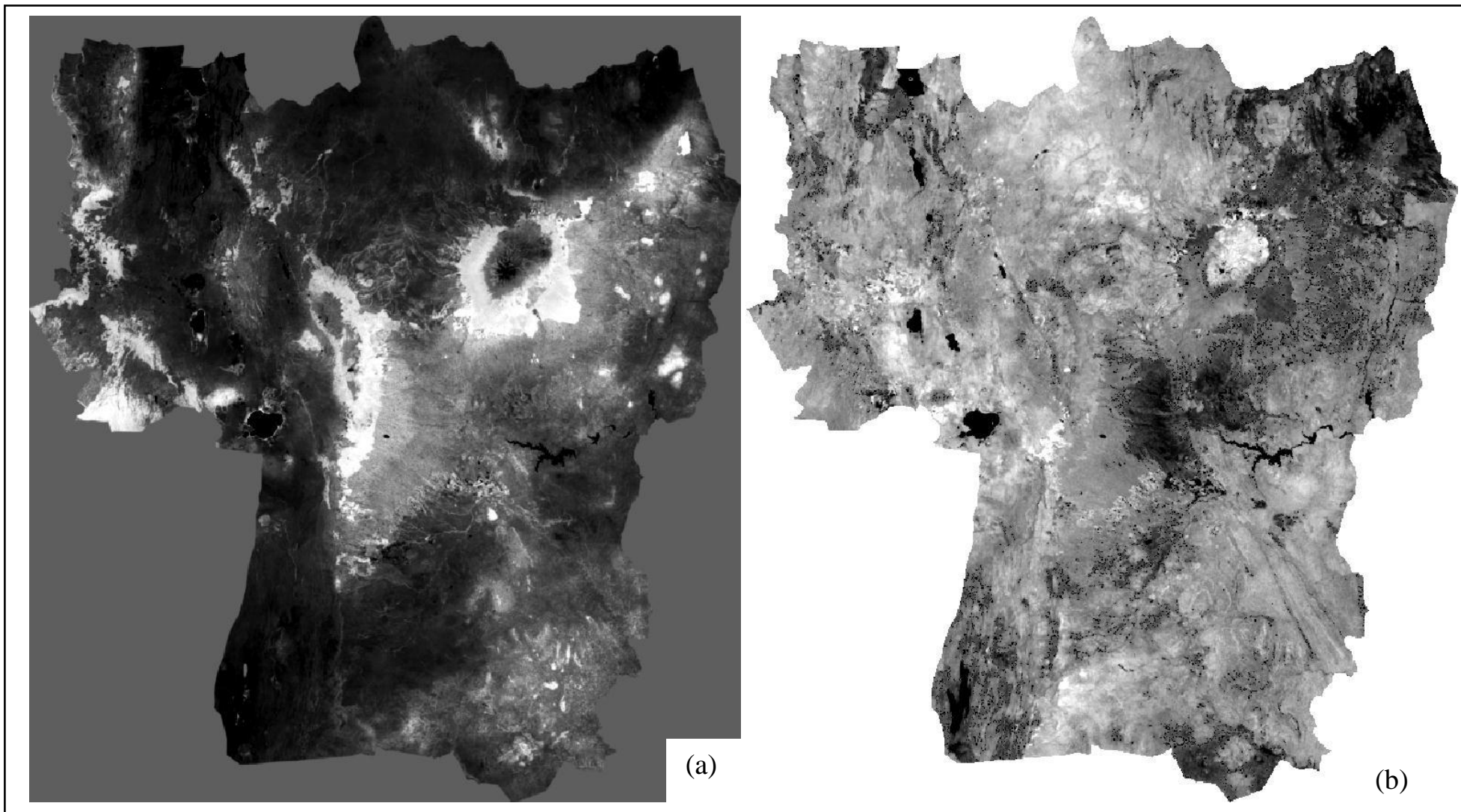

Figure 2(a): NDVI map (b) NDMIDR spectral index using Landsat 7, year 2000. Note that NDVI only emphasizes vegetated areas while NDMIDR emphasizes geological features and features improved texture
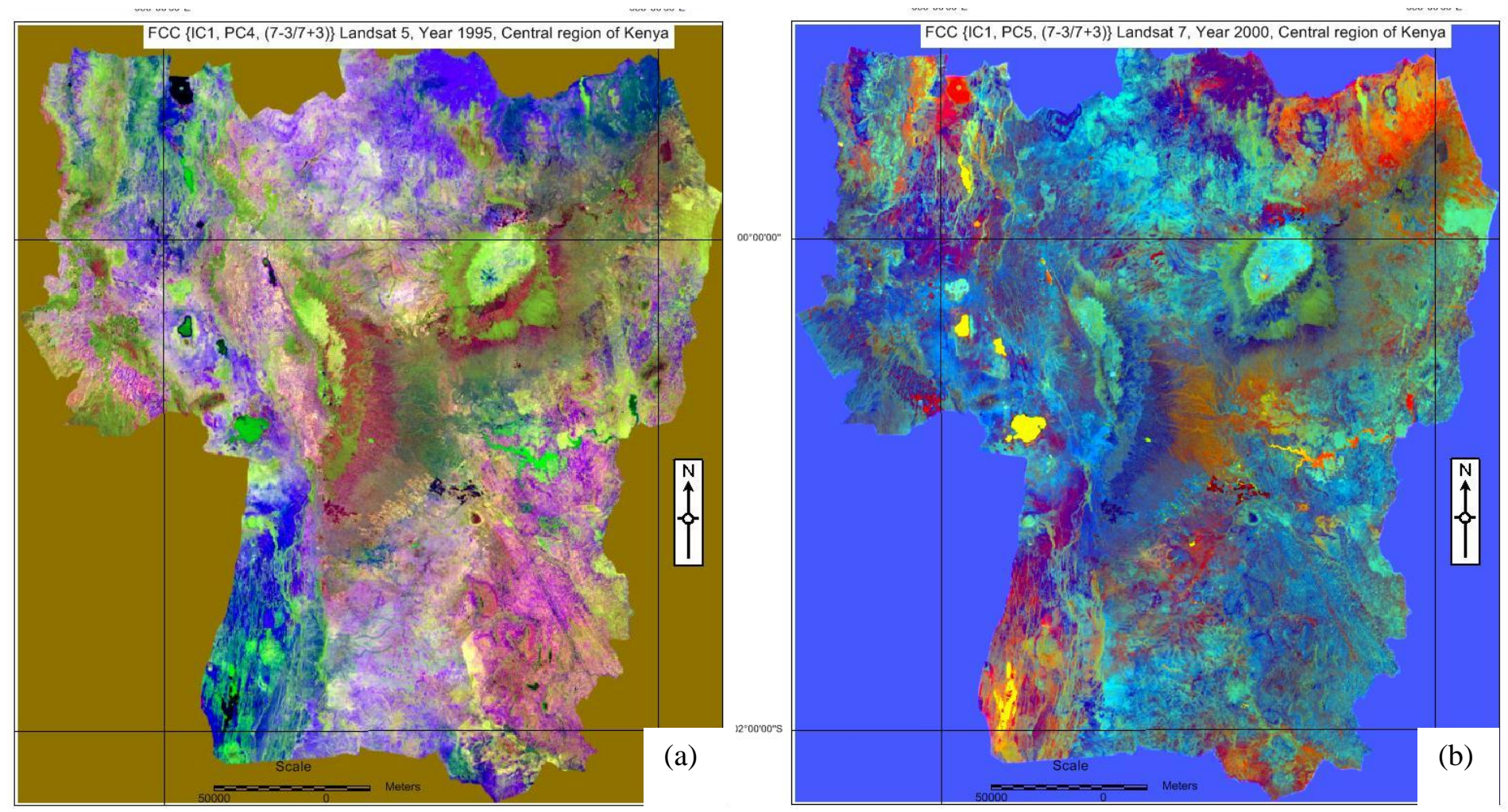

Figure 3: FCC combinations involving (a): IC1, PC4 and Spectral Index with bands $7 \& 3$ (b): IC1, PC5 and Spectral Index with bands $7 \& 3$ 


\subsection{Knowledge based classification}

The input variables to the knowledge based classification were the components of the FCC i.e. IC1, PC5, and NDMIDR for Landsat 7 and IC1,PC4 and NDMIDR for Landsat 5. The expert classification rules were from Hodgson et al. (2003), and involved generating rules from observed data using cognitive methods. The FCC was first visually examined followed by assigning major colours a particular class, after which a histogram of each FCC layer was examined noting the highest and lowest values. For each class, the file pixel values range was then examined and set in the knowledge based file by inquiring at various points having the same colour. A trial run classification was performed after which the rules and classes were refined further until all the values in each layer of the FCC had been assigned a class. The class boundaries set in the knowledge classifier are as presented in Table 3.

A total of 13 classes namely; runoff, extreme erosions, other erosions, landslide areas, highly erodible, stable, exposed volcanic rocks, agriculture areas, green forest, new forest regrowth, clear water, turbid water, salty water were identified and mapped as in Figures 4 and 5. Runoff was mainly bare sand deposits areas, while areas classified as extreme erosions were areas likely to experience erosions due to human influence from built up areas, settlements and overgrazing. Other erosions class represented areas likely to suffer erosion from agriculture activities (due to exposed bare soils), while highly erodible areas were mainly as a result of weathered volcanic rocks. Stable areas were mainly under grass cover while agriculture areas were mainly under crops and farmlands. 
Table 3: Classification boundaries

\begin{tabular}{|c|c|c|c|c|c|c|}
\hline \multirow[t]{2}{*}{ Classes } & \multicolumn{3}{|c|}{ Variables (classification, year 1995) } & \multicolumn{3}{|c|}{ Variables (classification, year 2000) } \\
\hline & IC1 & PC4 & NDMIDR & IC1 & PC5 & NDMIDR \\
\hline \multirow[t]{2}{*}{ Runoff } & $0.5--5$ & $<0$ & $>95$ & $0.35--0.25$ & $<-1.5$ & $0--0.20$ \\
\hline & & & & $1-0.75$ & $<-4.5$ & $0-0.05$ \\
\hline Extreme erosions & $<-0.90$ & $<1$ & $100-55$ & $6-1.25$ & $6--1.5$ & $-0.70-0.015$ \\
\hline Other erosions & $>1.5$ & $>6$ & $>110$ & $6-0.75$ & $-1.5--4.5$ & $0.075--0.45$ \\
\hline Landslide & $>2$ & $>6$ & $90-70$ & $<-0.11$ & $<-1.5$ & $<-0.035$ \\
\hline \multirow[t]{2}{*}{ Highly erodible } & $>0.75$ & $>5$ & $70-20$ & $<0.75$ & $6-0.5$ & $\geq 0.095$ \\
\hline & $2-0.5$ & $>5$ & $>70$ & & & \\
\hline \multirow[t]{2}{*}{ Stable } & $0.75--0.90$ & $<1.60$ & $>65$ & $0.75--0.114$ & $-1.5--7$ & $-0.06-0.099$ \\
\hline & & & & $1.8-0.75$ & $6-0.75$ & $0.05-0.25$ \\
\hline \multirow{4}{*}{$\begin{array}{l}\text { Exposed volcanic } \\
\text { rocks }\end{array}$} & $0.75--7$ & $15-5$ & $55-20$ & $<0.75$ & $\geq 6.5$ & $\geq 0.075$ \\
\hline & $<-1$ & $1--1$ & $24-18$ & $3--2$ & $\geq 9.2$ & $0.20--0.30$ \\
\hline & & & & $4.5--1.2$ & $9.2-6$ & $0.25-0$ \\
\hline & & & & $6-1.5$ & $20-6$ & $-0.250--0.035$ \\
\hline \multirow[t]{3}{*}{ Agricultural areas } & $3-0.5$ & $5--1$ & $150-30$ & $0.75--1.75$ & $6.5-0.3$ & $0.095-0.050$ \\
\hline & $0.75--0.90$ & $5-1.6$ & $>65$ & $1.5--1.5$ & $2.5-0.3$ & $0.05--0.06$ \\
\hline & $<-0.90$ & $2.0-1.75$ & $100-55$ & & & \\
\hline \multirow[t]{3}{*}{ Green Forest } & $0.90--5$ & $5--1$ & $65-20$ & $1.25--0.25$ & $2.5-0.3$ & $-0.06--0.37$ \\
\hline & & & & $1.4--1$ & $6-2.5$ & $0.05--0.37$ \\
\hline & & & & $1.5--1.2$ & $9.2-6.0$ & $0--0.37$ \\
\hline New Forest regrowth & $2.5--1.5$ & $<-1$ & $65-20$ & $\leq-0.25$ & $<0.3$ & $\geq 0$ \\
\hline Clear waters & $<0$ & $11-0$ & $<20$ & $6-1$ & $20-6$ & $<-0.25$ \\
\hline \multirow[t]{2}{*}{ Turbid water } & $<-2$ & $0--18$ & $<20$ & $6-1$ & $<6$ & $<-0.30$ \\
\hline & & & & $>6$ & $<0$ & $<0$ \\
\hline \multirow[t]{2}{*}{ Salty water } & $<-2$ & $<-13$ & $55-0$ & $>1$ & $>20$ & $<0$ \\
\hline & & & & $>6$ & $20-0$ & $>0$ \\
\hline
\end{tabular}

The FCC comprising IC, PC, and NDMIDR (Figure 3) displayed important surface characteristics of lithology, soil moisture and vegetation canopy moisture, which facilitated the classification mapping among landslide, erodible, deposit, stable, runoff, exposed volcanic rocks, vegetated areas and water cover. Specifically, the use of spectral index involving bands 
7 and 3 from Landsat TM/ETM+ as a Normalised Difference Index, helped to emphasize moisture content in vegetation and soils. This was due to use of SWIR band 7, which is sensitive to canopy moisture content (Vohora and Donoghue, 2004). The spectral index outperformed NDVI because the NDVI only emphasized the vegetated areas and provided fewer details about texture (Figure 2). In addition, Landsat band 7, which is predominantly used as a geology band, enhanced the NDMIDR spectral index by incorporating geology aspects, a factor associated with landsliding. The SWIR region is sensitive to clay bearing minerals while VNIR region provides some information about iron oxides as discussed by Abdeen et al. (2009). Therefore, NDMIDR spectral index highlighted clayey areas and possible deposit areas. The use of PC factor loading assisted to identify PCs containing most lithology and soils information from bands 5 and 7. The application of ICA further enhanced lithology features which could not be easily separated using PC1 which contained the most information from all bands.

The classification results obtained after running the classification rules in Table 3 are presented in Figures 4 and 5 for Landsat 5, year 1995 and Landsat 7, 2000 respectively. Landslide areas were mapped amongst other vegetated areas (green forest, new forest regrowth, agricultural areas), water or non-vegetated covers, which were associated with erodible areas (extreme erosions, highly erodible, other erosions), depositional areas (runoff, stable) or exposed volcanic rocks. To demonstrate the effectiveness of the classification, the results in figures 4 and 5 were blown out to a smaller section in the south-eastern side of the Aberdare ranges (Figure 6a and b) and overlaid with part of GPS field landslide vector layer conducted in February 2014. Further, Figure 6c gives an outlook of the steep-slope topography where the mapped landlides are located, while Figure 7 shows selected landslide sites photography taken during field work. 


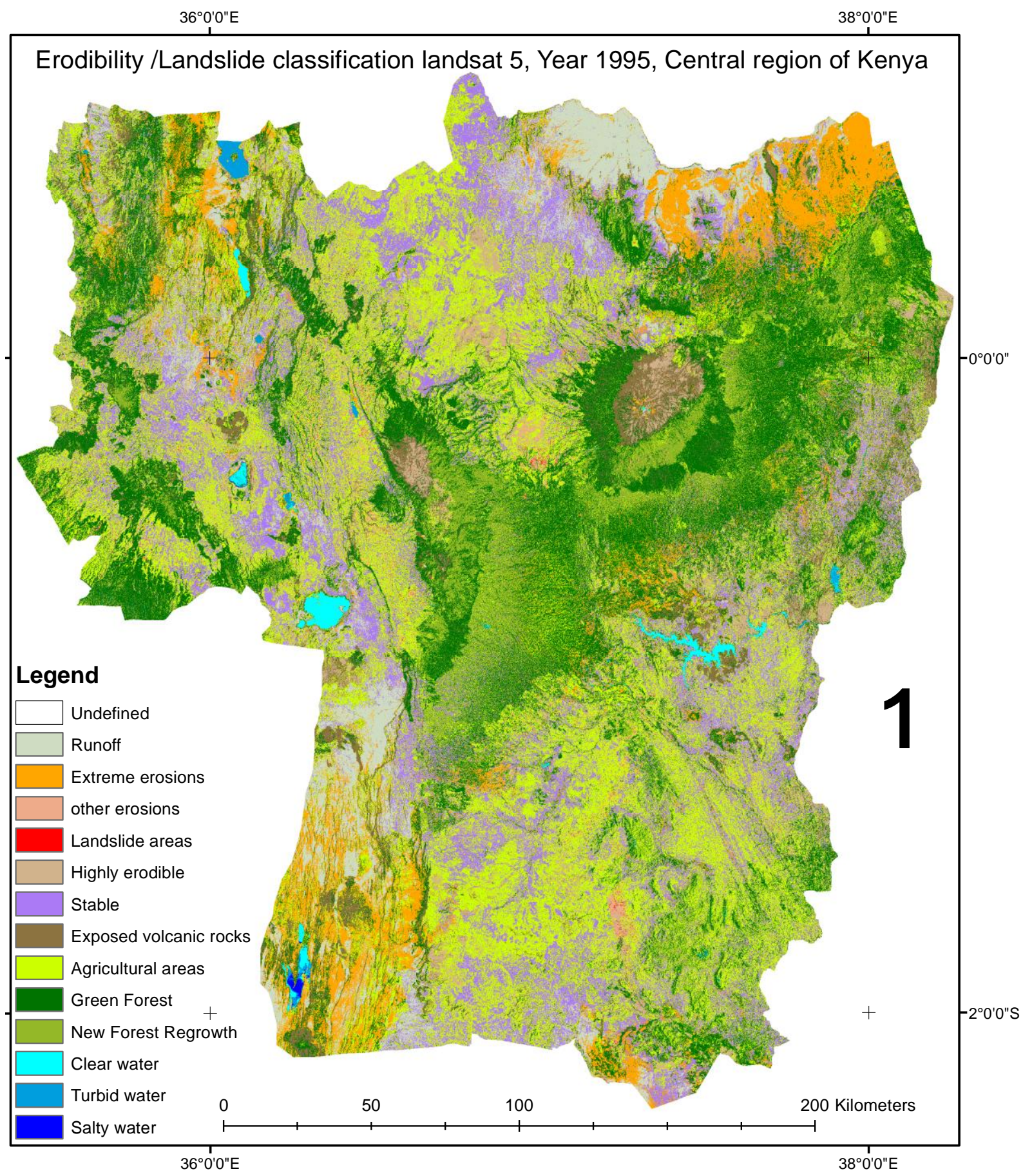

Figure 4: Erodibility/landslide classification $\{$ Inputs: IC1, PC4, band ratio index $\{7-3 / 7+3\}$, Year 1995 


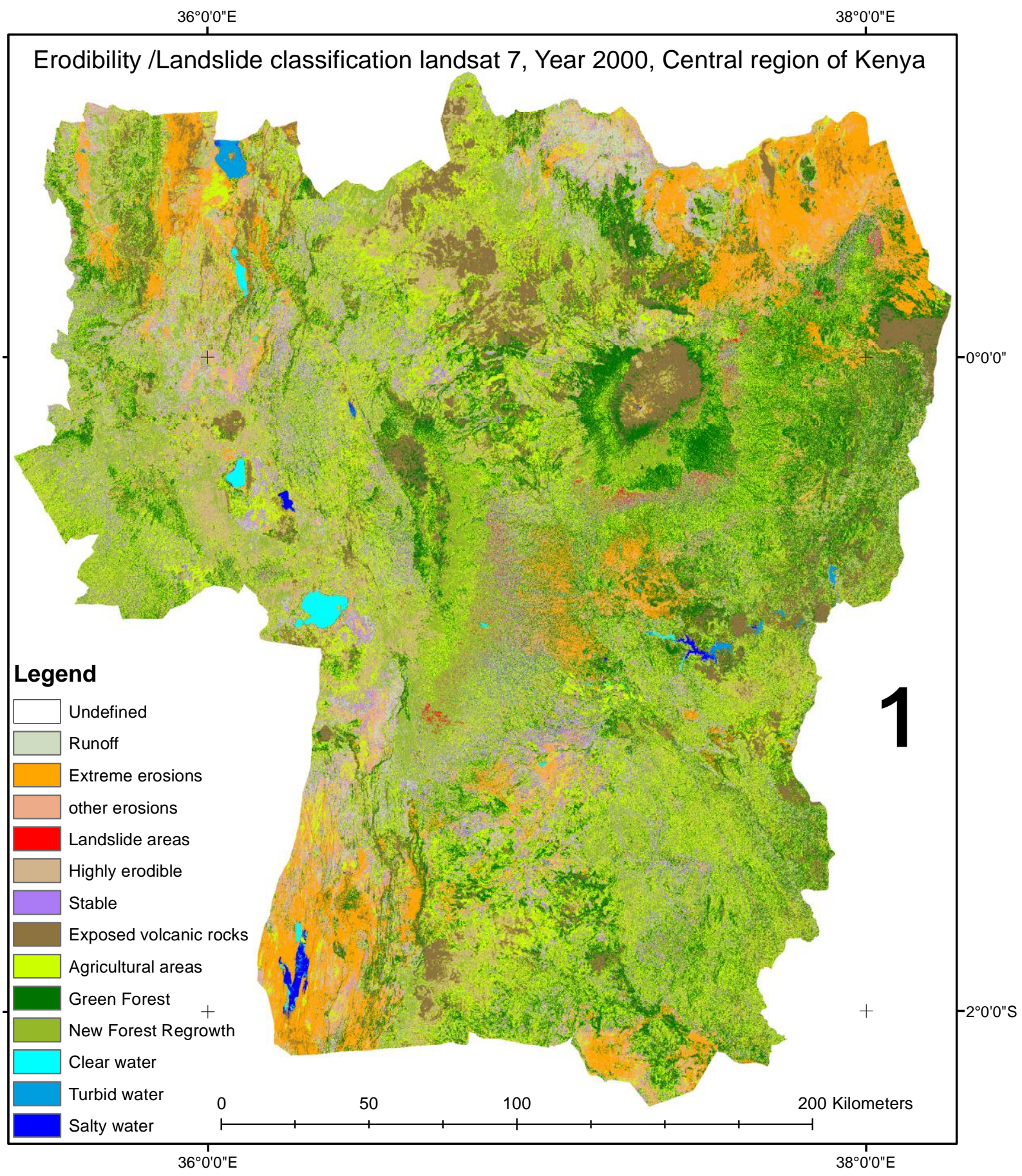

Figure 5: Erodibility/landslide classification $\{$ Inputs: IC1, PC5, band ratio index $\{7-3 / 7+3\}$, Year 2000 

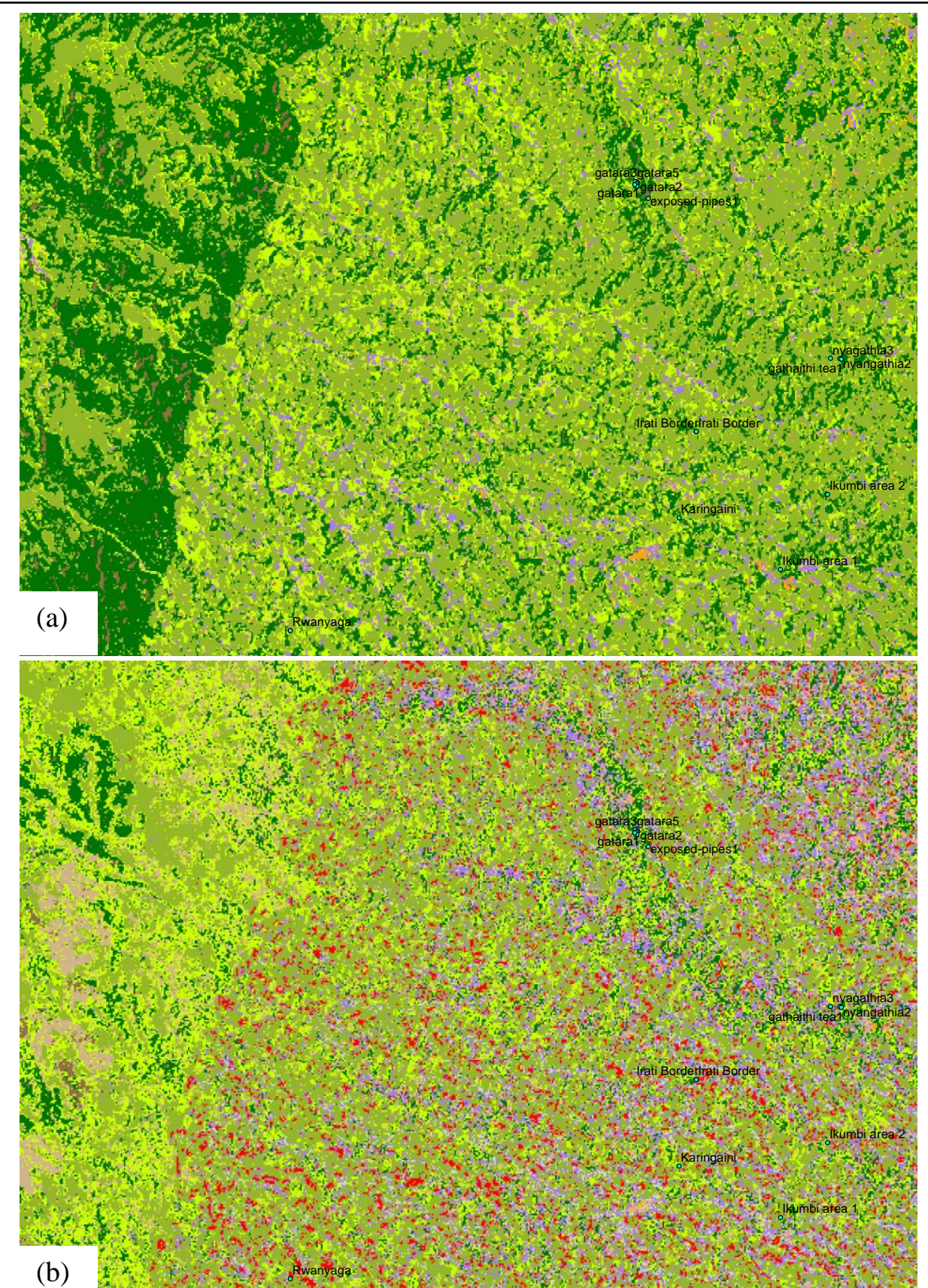

Figure 6: A blown out section of landslide prone area in Murang'a and Nyeri counties overlaid with landslide GPS field landslide vector layer

(a) Year 1995

(b) Year 2000

Figure 6 (c): A DEM Aspect map overlaid with classified landslide layer and GPS field landslide vector layer

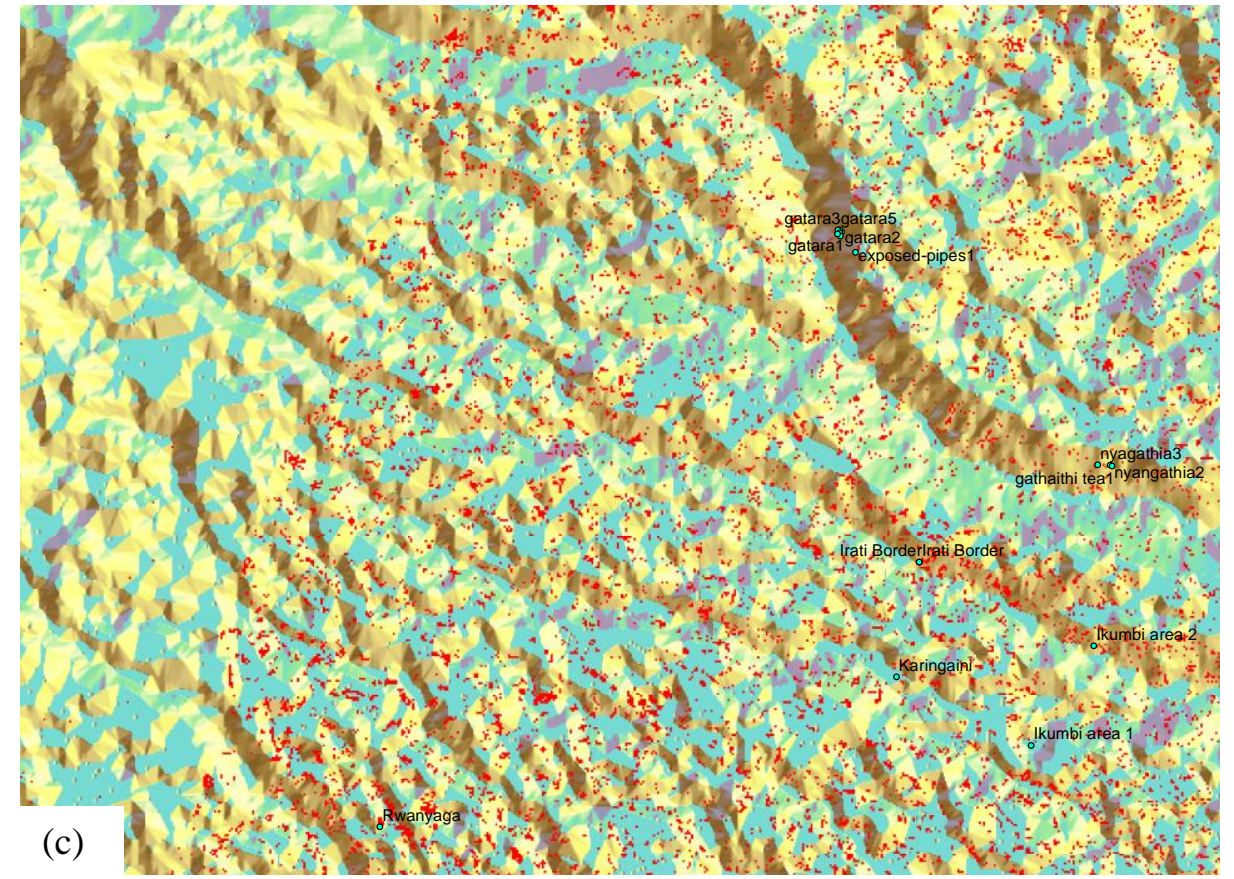




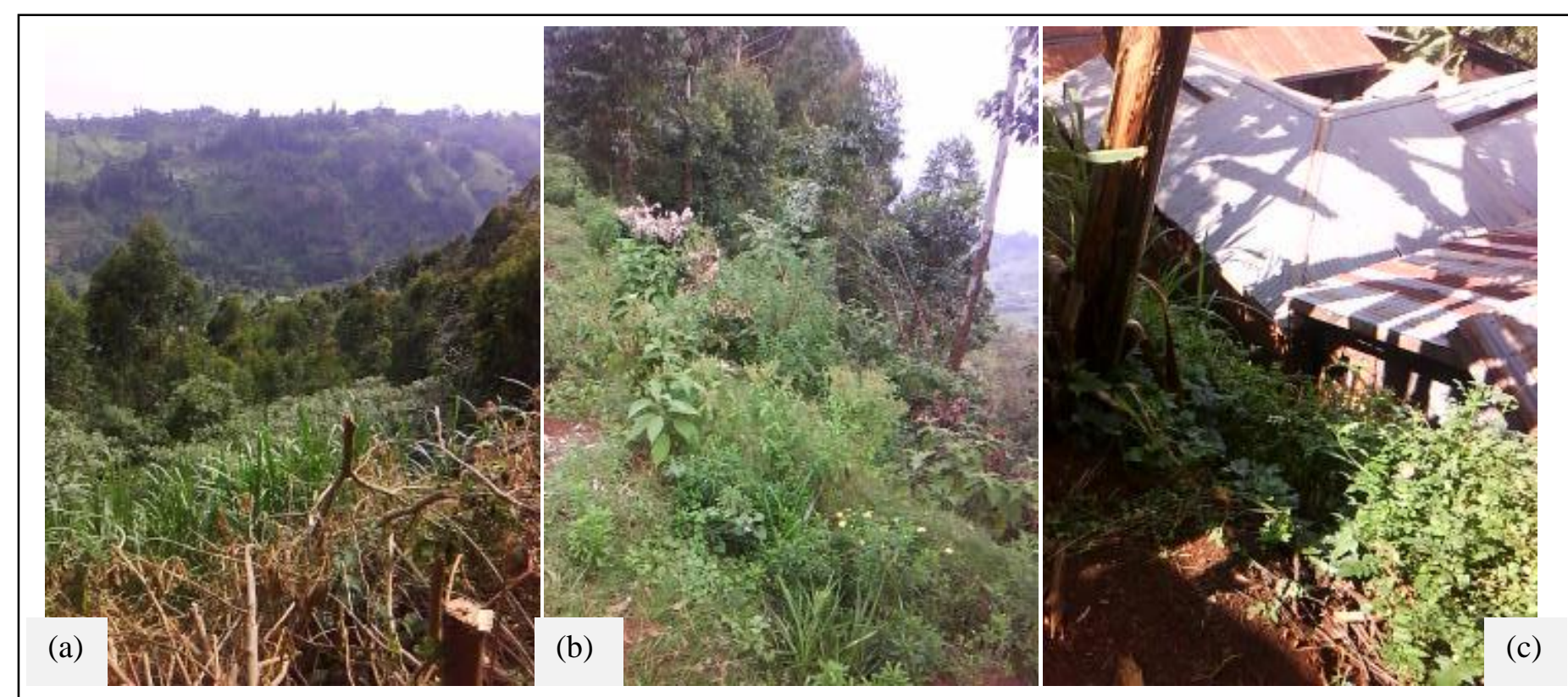

(a) Rehabilitated landslide in Nyagathia (b) Gatara-Mathwee area (c) deep loose layer of soil and a homestead below

(d)

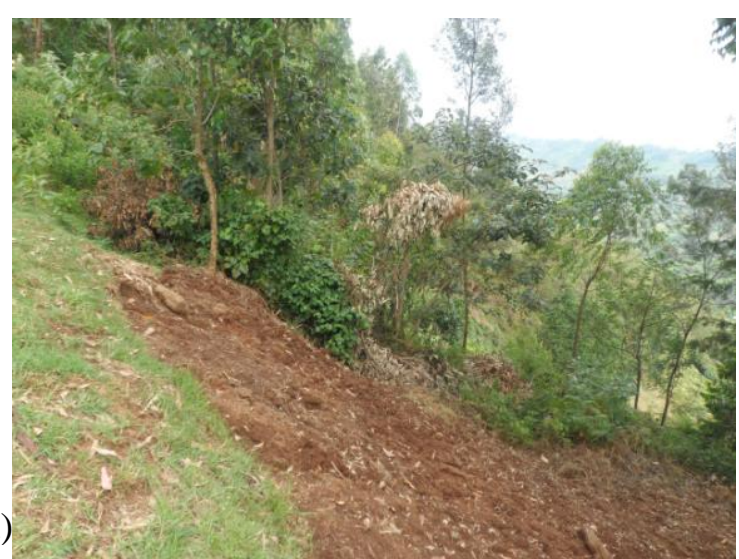

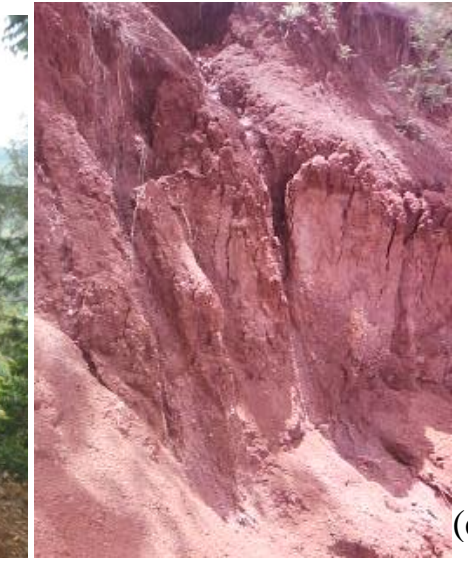

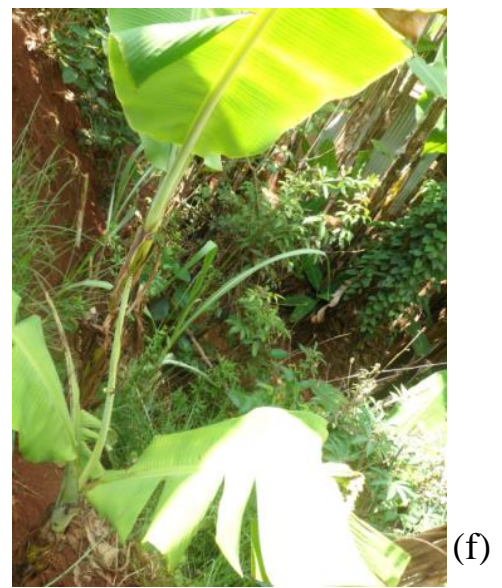

(d) Previous landslide site in Nyagathia area (e) loose thick soil layer awaiting trigger by the roadside, Kariua (f) Relocated plants in a homestead (Gatuya area)

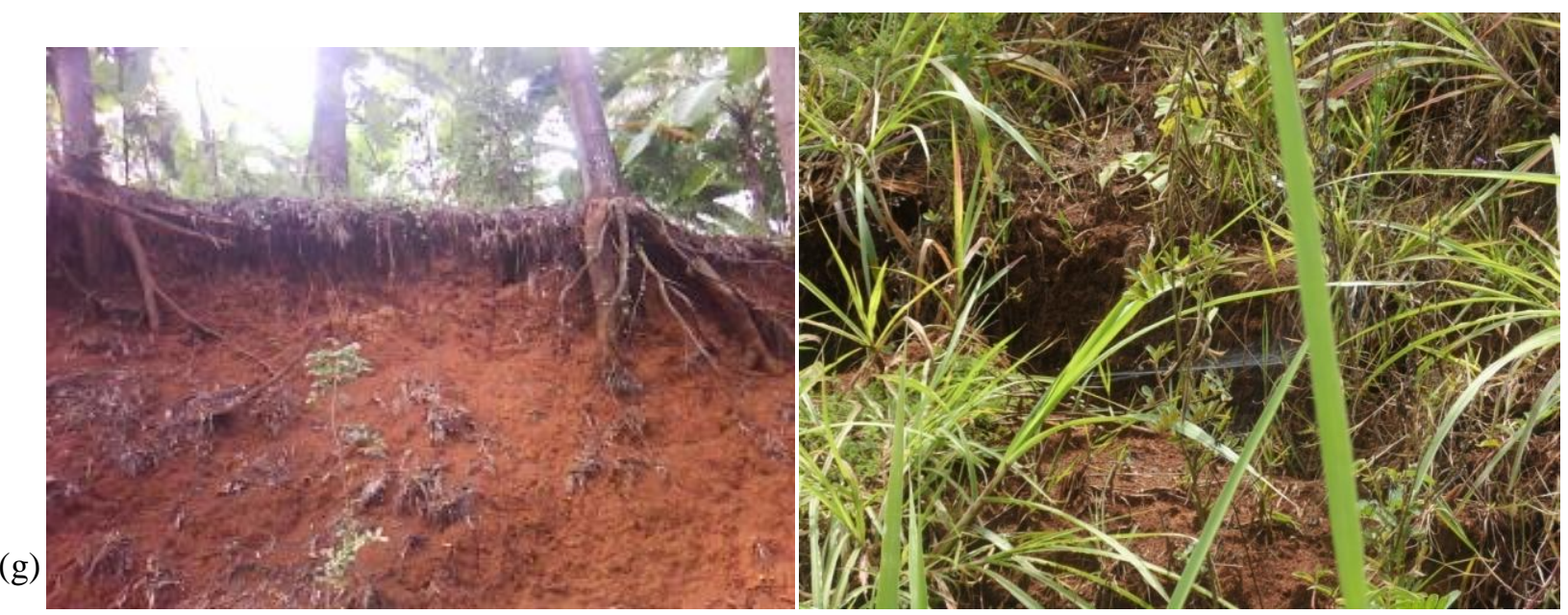

(h)

(g) Thick soil layers with roots only holding the top soil layers (h) inappropriate vegetation on already developing cracks

Figure 7: Various landslide sites in Murang'a county photos during fieldwork in February 2014 
The classification may serve to explain the contribution of land-use and rainfall to landsliding depicted in Figures 6(a) - (b), which captured the heavy El-Niño rains falling in the period between October 1997 and May 1998, whose devastating effects are recorded by Ngecu and Mathu (1999), followed by La-Niña drought in the years 1999 - 2000. The classification revealed increased landslide, erodible, and exposed volcanic rocks areas in the year 2000 compared to year 1995 (Table 4), while deposits areas decreased significantly, though water and vegetated areas remained almost constant. Of importance is the location of landslides 347 prevalence, i.e. within the other erosions areas and the transition area from forest areas to agricultural areas, where mainly tea and coffee are the main cash crops as observed during 349 field study (Figure 6b). This may have had a significant contribution to the increased 350 landsliding because the area is already vulnerable (Figure 6c, very steep slopes). Indeed, 351 increased soil erosion caused by poor agricultural practices may also have increased 352 landsliding. The increased erosion activity within the time epoch was in line with findings by 353 Malmstroem (1997) and Mburu et al. (2003), where sedimentation related to soil erosion and 354 precipitation was noted to cause volume change in Chinga dam.

Table 4: Representation of landslide areas in percentage in comparison to other covers

\begin{tabular}{|l|l|r|r|r|r|}
\hline & \multicolumn{1}{|c|}{ Classes } & $\mathbf{1 9 9 5}$ & $\mathbf{2 0 0 0}$ & \\
\hline Landslide areas & landslide areas & 0.19 & & 0.25 & \\
\hline Erodible areas & extreme erosion & 8.25 & 14.71 & 8.22 & 22.34 \\
\cline { 2 - 3 } & other erosion & 0.8 & & 8.19 & \\
\cline { 2 - 3 } & Highly erodible & 5.66 & & 5.93 & \\
\cline { 2 - 3 } Depositional areas & runoff & 6.37 & 23.60 & 4.09 & 11.50 \\
\cline { 2 - 3 } & stable & 17.23 & & 7.41 & \\
\hline Exposed volc. rocks & exposed volcanic rocks & 5.48 & & 10.54 & \\
\hline Vegetated areas & agriculture areas & 27.8 & & 27.26 & \\
\cline { 2 - 3 } & Green forest & 21.44 & 27.41 & 17.48 & 27.30 \\
\cline { 2 - 3 } & new forest regrowth & 5.97 & & 9.82 & \multirow{2}{*}{0.81} \\
\cline { 2 - 3 } & Clear water & 0.54 & 0.83 & 0.38 & \\
\cline { 2 - 3 } & Turbid water & 0.24 & & 0.22 & \\
\cline { 2 - 3 } & Salty water & 100 & & 100 & \\
\cline { 2 - 3 } & & & & 0.21 & \\
\hline
\end{tabular}


Exposed volcanic rocks areas had a significant increase from the general decrease in forest green cover and the removal of the weathered rock material in the highly erodible areas around the mountain caps (Figure 5). This might have been facilitated by the heavy El-Nino event, between years 1997-1998. Highly erodible zones were thus shifted to the stable areas leading to their significant reduction, an effect of overgrazing. Changes within the vegetation cover revealed decreased green forest cover and increased new forest regrowth areas, which may have a significant effect to increased new regrowth after the La-Nina drought. There was no significant change within agricultural areas, although loose thick soil layers were observed (Figure 7c, e, f, g) where the crop roots serve to hold only top soil layers and inappropriate shallow rooted vegetation, being cultivated on steep slopes (Figure $7 \mathrm{~h}$ ).

Landslides mapped through the classification were verified by comparison with sample GPS points previously mapped in a field study over the study area with $66 \%$ of the points coincided well with landslide areas mapped in the year 2000. This is because landslide rehabilitation takes place soon after the rainfall period is over (Figure 7 a \& b), thereby making it difficult to identify some landslide scars correctly. Instead, such areas were either new regrowth areas where vegetation cover was present or deposit/ runoff areas. Information from the local inhabitants was found to be useful in verifying the landuse activities (deforestation, over cultivation on very steep slopes, lack of proper water channels), thereby explaining why some GPS points coincided with erodible or depositional areas in the classification maps. The misclassification can be attributed to mixed pixels and the presence of vegetation cover in estimating soil attributes, which should be less than $20 \%$ (Bartholomeus et al., 2007).

The remote sensing methodology presented in this research can be improved further with the help of a high resolution Digital Elevation Model (DEM) in order to quantify the volume changes resulting from soil erosion and landsliding. This is in agreement with Mulder et al. 
(2011) who recommended use of DEM and soil profile sample data in studying soil attributes when using remote sensing data. Nevertheless, the method reveals the areas affected which can act as a guide to directing field work related to shallow landsliding or soil erosion. Moreover, the use of SAR imagery with the added advantage of texture, roughness details and higher spatial resolution, will greatly help to characterize the landslides and map line of weakness, where deep seated landslides may be triggered in the future. This will also help to resolve some of the mis-classification inaccuracies resulting from medium spatial resolution imagery (Lu and Weng, 2007) such as Landsat, although it's higher spectral resolution coupled with image enhancements for landslide mapping have benefitted this research.

\section{Conclusions and recommendations}

Modified NDMIDR index in conjunction with image enhancement techniques (ICA, PCA, and FCC) have successfully been used to map and identify landslide scars as well as soil erodibility as a factor of land degradation. From the duration of study, applying images of 1995 and 2000, the study captured the 1997/98 El-Niño rainfall impacts in which more erosion and landslide areas increased following the heavy rains. In addition, the classification also captured the contributions of land-use to the increasing land degradation, thus exacerbating landslide activities and soil erodibility events on hazard prone areas.

The classification maps showed landslide areas on the steep ridge faces, other erosions in agricultural areas, highly eroble zones being already weathered rocks, while runoff were mainly fluvial deposits. The results obtained in this study can form the basis for landslide suceptibility mapping for the study area considering other landslide factors such as: slope, closeness to drainages and roads, changes in landuse, geology, rainfall, soil properties and aspect. Also, the application of the methodology on other Landsat series data for other years together with high resolution DEM data, can assist to quantify landslide associated losses in terms of the extent of the areas affected and counter measures taken. Similarly, it is possible 
to create a landslide inventory database together with field data in areas where they do not

exist.

\section{Acknowledgements}

We would like to thank all the anonymous reviewers for their contribution to improve the quality of this paper. We also acknowledge support from USGS website for the Landsat imagery and thank DAAD/NACOSTI post graduate research programme for their support, and the Jomo Kenyatta University of Agriculture and Technology for its continued support including conducting field work and staff training programme.

\section{References}

Abdeen, M.M., Hassan, S.M., El-Kazzaz, Y.A.H.A., Attia, G.M., and Yehia, M.A. (2009). Mapping Geological Structures In Wadi Ghoweibaarea, Northwest Gulf Of Suez, Egypt, Using Aster-Spot Data Fusion And Aster DEM. Egypt. J. Remote Sens. Space Sci. 12, 101-126.

Alatorre, L.C., and Beguería, S. (2009). Identification of eroded areas using remote sensing in a badlands landscape on marls in the central Spanish Pyrenees. CATENA 76, 182-190.

Alimohammadlou, Y., Najafi, A., and Yalcin, A. (2013). Landslide process and impacts: A proposed classification method. CATENA 104, 219-232.

Alkhasawneh, M.S., Ngah, U.K., Tay, L.T., Mat Isa, N.A., and Al-batah, M.S. (2013). Determination of Important Topographic Factors for Landslide Mapping Analysis Using MLP Network. Sci. World J. $2013,1-12$.

Ardavan, G., Amir, M.M., and Abazar, E.O. (2012). Utility of the NDVI for land/canopy cover mapping in Khalkhal County (Iran). Ann. Biol. Res. 3, 5494-5503.

Arekhi, S., Bolourani, A.D., Shabani, A., Fathizad, H., and Ahamdy-Asbchin, S. (2012). Mapping soil erosion and sediment yield susceptibility using RUSLE, remote sensing and GIS (Case study: Cham Gardalan watershed, Iran). Adv. Environ. Biol. 6, 109-124.

Baade, J., and Schmullius, C.C. (2010). Interferometric Microrelief Sensing With TerraSAR-X: First Results. IEEE Trans. Geosci. Remote Sens. 48, 965-970.

Baroudy, A.A. El (2011). Monitoring land degradation using remote sensing and GIS techniques in an area of the middle Nile Delta, Egypt. Catena 87, 201-208.

Baroudy, A.A. El, and Moghanm, F.S. (2014). Combined use of remote sensing and GIS for degradation risk assessment in some soils of the Northern Nile Delta, Egypt. Egypt. J. Remote Sens. Space Sci. $17,77-85$.

Barrett, B.W., Dwyer, E., and Whelan, P. (2009). Soil Moisture Retrieval from Active Spaceborne Microwave Observations: An Evaluation of Current Techniques. Remote Sens. 1, 210-242. 
Bartholomeus, H., Epema, G., and Schaepman, M. (2007). Determining iron content in Mediterranean soils in partly vegetated areas, using spectral reflectance and imaging spectroscopy. Int. J. Appl. Earth Obs. Geoinformation 9, 194-203.

Bhandari, K.P., Aryal, J., and Darnsawasdi, R. (2015). A geospatial approach to assessing soil erosion in a watershed by integrating socio-economic determinants and the RUSLE model. Nat. Hazards 75, $321-342$.

Blasch, G., Spengler, D., Hohmann, C., Neumann, C., Itzerott, S., and Kaufmann, H. (2015). Multitemporal soil pattern analysis with multispectral remote sensing data at the field-scale. Comput. Electron. Agric. 113, 1-13.

Bonn, F., Megier, J., and Fora, A.A. (1996). Remote sensing assisted spatialization of soil erosion models with a GIS for land degradation quantification: expectations, errors and beyond. In Proceedings of the 16th EARSeL Symposium, (Malta: CRC Press), pp. 191-198.

Bright, A., Hammell, R., and van Aardt, J. (2010). Identification of spectral Indicators in Vegetation Disturbance (Chester F. Carlson Centre for Imaging Science, Rochester Institute of Technology).

Campbell, J.B. (1996). Introduction to remote sensing (New York: Guilford Press, New York).

Campbell, J.B. (2009). Remote sensing of Soils. In The Sage Handbook of Remote Sensing, (Thousand Oaks, CA: Sage), pp. 341-354.

Ceccato, P., Gobron, N., Flasse, S., Pinty, B., and Tarantola, S. (2002). Designing a spectral index to estimate vegetation water content from remote sensing data: Part 1. Remote Sens. Environ. 82, 188197.

Chang, C.-I., and Wang, S. (2006). Constrained band selection for hyperspectral imagery. IEEE Trans. Geosci. Remote Sens. 44, 1575-1585.

Chen, X., and Campagna, D.J. (2009). Remote Sensing of Geology. In The Sage Handbook of Remote Sensing, (Thousand Oaks, CA: Sage), pp. 328-340.

Daughtry, S.T.C., Hunt, E.R., and McMurtrey III, J.E. (2004). Assessing crop residue cover using shortwave infrared reflectance. Remote Sens. Environ. 90, 126-134.

Deng, Y., Wu, C., Li, M., and Chen, R. (2015). RNDSI: A ratio normalized difference soil index for remote sensing of urban/suburban environments. Int. J. Appl. Earth Obs. Geoinformation 39, 40-48.

Desprats, J.F., Raclot, D., Rousseau, M., Cerdan, O., Garcin, M., Le Bissonnais, Y., Ben Slimane, A., Fouche, J., and Monfort-Climent, D. (2013). Mapping linear erosion features using high and very high resolution satellite imagery. Land Degrad. Dev. 24, 22-32.

Dewitte, O., Jones, A., Elbelrhiti, H., Horion, S., and Montanarella, L. (2012). Satellite remote sensing for soil mapping in Africa: An overview. Prog. Phys. Geogr. 36, 514-538.

Dhakal, A.S., Amada, T., Aniya, M., and Rishi, R.S. (2002). Detection of areas associated with flood and erosion caused by a heavy rainfall using multitemporal Landsat TM data. Photogramm. Eng. Remote Sens. 68, 233-239.

Epting, J., Verbyla, D., and Sorbel, B. (2005). Evaluation of remotely sensed indices for assessing burn severity in interior Alaska using Landsat TM and ETM+. Remote Sens. Environ. 96, 328-339.

Fernández, T., Jiménez, J., Fernández, P., Hamdouni, R. El, Cardenal, F.J., Delgado, J., Irigaray, C., and Chacón, J. (2008). Automatic detection of landslide features with RS techniques in the betic 
cordilleras (Granada, Southern Spain). Int. Arch. Photogramm. Remote Sens. Spat. Inf. Sci. 37, 351356.

Gao, J., and Liu, Y. (2008). Mapping of land degradation from space: a comparative study of Landsat ETM+ and ASTER data. Int. J. Remote Sens. 29, 4029-4043.

Gao, J., and Liu, Y. (2010). Determination of land degradation causes in Tongyu County, Northeast China via land cover change detection. Int. J. Appl. Earth Obs. Geoinformation 12, 9-16.

Garbulsky, M.F., Peñuelas, J., Gamon, J., Inoue, Y., and Filella, I. (2011). The photochemical reflectance index (PRI) and the remote sensing of leaf, canopy and ecosystem radiation use efficiencies: A review and meta-analysis. Remote Sens. Environ. 115, 281-297.

Glenn, E.P., Huete, A.R., Nagler, P.L., and Nelson, S.G. (2008). Relationship Between Remotelysensed Vegetation Indices, Canopy Attributes and Plant Physiological Processes: What Vegetation Indices Can and Cannot Tell Us About the Landscape. Sensors 8, 2136-2160.

Govaerts, B., and Verhulst, N. (2010). The normalized difference vegetation index (NDVI) GreenSeeker TM handheld sensor: Toward the integrated evaluation of crop management. Part A: Concepts and case studies. (Mexico: International Maize and Wheat Improvement Center (CIMMYT)).

Govender, M., Chetty, K., and Bulcock, H. (2007). A review of hyperspectral remote sensing and its application in vegetation and water resource studies. Water SA 33, 145-152.

Guerschman, J.P., Scarth, P.F., McVicar, T.R., Renzullo, L.J., Malthus, T.J., Stewart, J.B., Rickards, J.E., and Trevithick, R. (2015). Assessing the effects of site heterogeneity and soil properties when unmixing photosynthetic vegetation, non-photosynthetic vegetation and bare soil fractions from Landsat and MODIS data. Remote Sens. Environ. 161, 12-26.

Guzzetti, F., Mondini, A.C., Cardinali, M., Fiorucci, F., Santangelo, M., and Chang, K.-T. (2012). Landslide inventory maps: New tools for an old problem. Earth-Sci. Rev. 112, 42-66.

Highland, L., and Bobrowsky, P.T. (2008). The Landslide handbook: a guide to understanding landslides (Reston, VA: US Geological Survey).

Hochschild, V., Märker, M., Rodolfi, G., and Staudenrausch, H. (2003). Delineation of erosion classes in semi-arid southern African grasslands using vegetation indices from optical remote sensing data. Hydrol. Process. 17, 917-928.

Hodgson, M.E., Jensen, J.R., Tullis, J.A., Riordan, K.D., and Archer, C.M. (2003). Synergistic Use of Lidar and Color Aerial Photography for Mapping Urban Parcel Imperviousness. Photogramm. Eng. Remote Sens. 69, 973-980.

Jensen, J.R. (2007). Remote Sensing of vegetation. In Remote Sensing of the Environment: An Earth Resource Perspective, (Upper Saddle River, NJ: Pearson Prentice Hall),

Jensen, R.J., Jungho, I., Hardin, P., and Jensen, R.R. (2009). Image classification. In The Sage Handbook of Remote Sensing, (Thousand Oaks, CA: Sage), pp. 269-282.

Kim, J.B., Saunders, P., and Finn, J.T. (2005). Rapid Assessment of Soil Erosion in the Rio Lempa Basin, Central America, Using the Universal Soil Loss Equation and Geographic Information Systems. Environ. Manage. 36, 872-885. 
Kim, S.M., Jang, T.I., Kang, M.S., Im, S.J., and Park, S.W. (2014). GIS-based lake sediment budget estimation taking into consideration land use change in an urbanizing catchment area. Environ. Earth Sci. 71, 2155-2165.

Kipchumba, I.K. (2011). Landslide Hazard assement in Kenya. Bsc Project. University of Nairobi.

Kipkiror, L.J., and Towett, J. (2013). Towards Ensuring a supply of sufficient and Quality water in the Lagam Escapment and the kerio valley in Marakwet District, Kenya. Int. J. Humanit. Soc. Sci. 3, 231241.

Kipseba, E.K., Ogora, M., Maina, G., and Kotut, J. (2013). Preliminary reports on Kijabe Landslides, Lari District, Kiambu County (Nairobi, Kenya: Ministry of Environment and Mineral Resources).

Lal, R. (2001). Soil degradation by erosion. Land Degrad. Dev. 12, 519-539.

Lee, S., and Pradhan, B. (2006). Probabilistic landslide hazards and risk mapping on Penang Island, Malaysia. J. Earth Syst. Sci. 115, 661-672.

Liao, Z., Hong, Y., Kirschbaum, D., and Liu, C. (2012). Assessment of shallow landslides from Hurricane Mitch in central America using a physically based model. Environ. Earth Sci. 66, 16971705.

Lu, D., and Weng, Q. (2007). A survey of image classification methods and techniques for improving classification performance. Int. J. Remote Sens. 28, 823-870.

Lu, D., Batistella, M., Mausel, P., and Moran, E. (2007). Mapping and monitoring land degradation risks in the Western Brazilian Amazon using multitemporal Landsat TM/ETM+ images. Land Degrad. Dev. 18, 41-54.

Maina-Gichaba, C., Kipseba, E.K., and Masibo, M. (2013). Overview of Landslide Occurrences in Kenya. In Developments in Earth Surface Processes, (Elsevier), pp. 293-314.

Malmstroem, M. (1997). Volume change of Chinga Dam, Othaya Division, Kenya: A study of sedimentation related to mass movements, soil erosion and precipitation (Uppsala: Swedish University of Agriculture Sciences).

Mašková, Z., Zemek, F., and Květ, J. (2008). Normalized difference vegetation index (NDVI) in the management of mountain meadows. Boreal Environ. Res. 13, 417-432.

Mburu, D.M., Westerberg, L.-O., Sandel, J., and Malmstroem, M. (2003). Mass movement and sedimentation of Chinga Dam in Othaya Division, Kenya. In Proceedings of the International Conference on Local Land Use Strategies Ina Globalizing World, (Institute of Geography, University of Copenhagen, Denmark), pp. 329-339.

Metternicht, G., Zinck, J.A., Blanco, P.D., and del Valle, H.F. (2010). Remote Sensing of Land Degradation: Experiences from Latin America and the Caribbean. J. Environ. Qual. 39, 42.

Meusburger, K., Konz, N., Schaub, M., and Alewell, C. (2010). Soil erosion modelled with USLE and PESERA using QuickBird derived vegetation parameters in an alpine catchment. Int. J. Appl. Earth Obs. Geoinformation 12, 208-215.

Meyer, G.A., Pierce, J.L., Wood, S.H., and Jull, A.J.T. (2001). Fire, storms, and erosional events in the Idaho batholith. Hydrol. Process. 15, 3025-3038.

Mondini, A.C., Chang, K.-T., and Yin, H.-Y. (2011). Combining multiple change detection indices for mapping landslides triggered by typhoons. Geomorphology 134, 440-451. 
Moreno-Madriñán, M.J., Rickman, D.L., Ogashawara, I., Irwin, D.E., Ye, J., and Al-Hamdan, M.Z. (2015). Using remote sensing to monitor the influence of river discharge on watershed outlets and adjacent coral Reefs: Magdalena River and Rosario Islands, Colombia. Int. J. Appl. Earth Obs. Geoinformation 38, 204-215.

Mulder, V.L., de Bruin, S., Schaepman, M.E., and Mayr, T.R. (2011). The use of remote sensing in soil and terrain mapping - A review. Geoderma 162, 1-19.

Mumby, P.J., Green, E.P., Edwards, A.J., and Clark, C.D. (1999). The cost-effectiveness of remote sensing for tropical coastal resources assessment and management. J. Environ. Manage. 55, 157-166.

Mutekanga, F.P., Visser, S.M., and Stroosnijder, L. (2010). A tool for rapid assessment of erosion risk to support decision-making and policy development at the Ngenge watershed in Uganda. Geoderma $160,165-174$.

Mwaniki, M.W., Ngigi, T.G., and Waithaka, E.H. (2011). Rainfall Induced Landslide Probability Mapping for Central Province. In Fourth International Summer School and Conference, (JKUAT, Kenya: Publications of AGSE Karlsruhe, Germany), pp. 203-213.

Mwaniki, M.W., Matthias, M.S., and Schellmann, G. (2015). Application of Remote Sensing Technologies to Map the Structural Geology of Central Region of Kenya. IEEE J. Sel. Top. Appl. Earth Obs. Remote Sens. 8, 1855-1867.

Nadal-Romero, E., Regüés, D., Martí-Bono, C., and Serrano-Muela, P. (2007). Badland dynamics in the Central Pyrenees: temporal and spatial patterns of weathering processes. Earth Surf. Process. Landf. 32, 888-904.

Nagler, P.L., Daughtry, S.T.C., and Goward, S.N. (2000). Plant litter and soil reflectance. Remote Sens. Environ. 71, 207-215.

Ngecu, W.M., and Mathu, E.M. (1999). The El-Nino- triggered landslides and their socio-economic impact on Kenya. Eng. Geol. 38, 277-285.

Ngecu, W.M., Nyamai, C.M., and Erima, G. (2004). The extent and significance of mass-movements in Eastern Africa: case studies of some major landslides in Uganda and Kenya. Environ. Geol. 46, $1123-1133$.

Nield, S.J., Boettinger, J.L., and Ramsey, R.D. (2007). Digitally Mapping Gypsic and Natric Soil Areas Using Landsat ETM Data. Soil Sci. Soc. Am. J. 71, 245-252.

Ogallo, S.N., Gaya, C.O., and Omuterema, S.O. (2006). Landslide Hazard Zonation Mapping for Murang'a District, Kenya. In Proceedings of the 1st International Conference on Disaster Management \& Human Security in Africa, (Masinde Muliro University of Science \& Technology, Kakamega, Kenya: Center for Disaster Management \& Humanitarian Assisstance), pp. 303-308.

Ogora, M., and Kotut, J. (2013). Report on Yatta Landslide, Machakos County (Nairobi, Kenya: Ministry of Environment and Mineral Resources).

Panagos, P., Karydas, C.G., Gitas, I.Z., and Montanarella, L. (2012). Monthly soil erosion monitoring based on remotely sensed biophysical parameters: a case study in Strymonas river basin towards a functional pan-European service. Int. J. Digit. Earth 5, 461-487.

Petley, D.N., Crick, W.D.., and Hart, A.B. (2002). The use of satellite imagery in landslide studies in high mountain area. In Proceedings of the 23rd Asian Conference on Remote Sensing, (Kathmandu, Nepal), pp. 2-9. 
Pradhan, B., Chaudhari, A., Adinarayana, J., and Buchroithner, M.F. (2012). Soil erosion assessment and its correlation with landslide events using remote sensing data and GIS: a case study at Penang Island, Malaysia. Environ. Monit. Assess. 184, 715-727.

Purevdorj, T., Tateishi, R., Ishiyama, T., and Honda, Y. (1998). Relationships between percent vegetation cover and vegetation indices. Int. J. Remote Sens. 19, 3519-3535.

Ramli, M.F., Yusof, N., Yusoff, M.K., Juahir, H., and Shafri, H.Z.M. (2010). Lineament mapping and its application in landslide hazard assessment: a review. Bull. Eng. Geol. Environ. 69, 215-233.

Rawashdeh, S.A., Saleh, B., and Hamzah, M. (2006). The use of Remote Sensing Technology in geological Investigation and mineral Detection in El Azraq-Jordan. Cybergeo Eur. J. Geogr. 358.

Robinson, D.A., and Moses, A. (2011). Rock surface and Weathering: Process and Form. In The SAGE Handbook of Geomorphology, (Los Angeles; London: SAGE), pp. 291-309.

Roering, J.J., Schmidt, K.M., Stock, J.D., Dietrich, W.E., and Montgomery, D.R. (2003). Shallow landsliding, root reinforcement, and the spatial distribution of trees in the Oregon Coast Range. Can. Geotech. J. 40, 237-253.

Rott, H., and Nagler, T. (2006). The contribution of radar interferometry to the assessment of landslide hazards. Adv. Space Res. 37, 710-719.

Sajadi, S. (2011). A relationship between NDVI and tasseled cap techniques. Geospatial World Newsl. 460.

Schmidt, K.M., Roering, J.J., Stock, J.D., Dietrich, W.E., Montgomery, D.R., and Schaub, T. (2001). The variability of root cohesion as an influence on shallow landslide susceptibility in the Oregon Coast Range. Can. Geotech. J. 38, 995-1024.

Shruthi, R.B.V., Kerle, N., and Jetten, V. (2011). Object-based gully feature extraction using high spatial resolution imagery. Geomorphology 134, 260-268.

Sims, D.A., and Gamon, J.A. (2002). Relationships between leaf pigment content and spectral reflectance across a wide range of species, leaf structures and developmental stages. Remote Sens. Environ. 81, 337-354.

Singh, D., Herlin, I., Berroir, J.., Silva, E.., and Simoes Meirelles, M. (2004). An approach to correlate NDVI with soil colour for erosion process using NOAA/AVHRR data. Adv. Space Res. 33, 328-332.

Smith, L.C., Alsdorf, D.E., Magilligan, F.J., Gomez, B., Mertes, L.A.K., Smith, N.D., and Garvin, J.B. (2000). Estimation of erosion, deposition, and net volumetric change caused by the 1996 Skeiðarársandur jökulhlaup, Iceland, from Synthetic Aperture Radar Interferometry. Water Resour. Res. 36, 1583-1594.

Song, C., Woodcock, C.E., Seto, K.C., Lenney, M.P., and Macomber, S.A. (2001). Classification and Change Detection Using Landsat TM Data. Remote Sens. Environ. 75, 230-244.

Taherynia, M.H., Mohammadi, M., and Ajalloeian, R. (2014). Assessment of Slope Instability and Risk Analysis of Road Cut Slopes in Lashotor Pass, Iran. J. Geol. Res. 2014, 1-12.

Thenot, F., Méthy, M., and Winkel, T. (2002). The Photochemical Reflectance Index (PRI) as a waterstress index. Int. J. Remote Sens. 23, 5135-5139.

Tsutsui, K., Rokugawa, S., Nakagawa, H., Miyazaki, S., Cheng, C.-T., Shiraishi, T., and Yang, S.-D. (2007). Detection and Volume Estimation of Large-Scale Landslides Based on Elevation-Change 
641

642

643

644

645

646

647

648

649

650

651

652

653

654

655

656

657

658

659

660

661

662

663

664

665

666

667

668

669

670

671

672

673

Vohora, V.K., and Donoghue, S.L. (2004). Application of remote Sensing data to Landslide mapping in Hong Kong. Int. Arch. Photogramm. Remote Sens. GIS V, 489-494.

Vorovencii, I. (2007). Use of the "Tasseled Cap" Transformation for the Interpretation of Satellite Images. Cadastre J. RevCAD 75-82.

Vrieling, A. (2006). Satellite remote sensing for water erosion assessment: A review. CATENA 65, $2-$ 18.

Wang, C., Jiang, R., Mao, X., Sauvage, S., Sánchez-Pérez, J.-M., Woli, K.P., Kuramochi, K., Hayakawa, A., and Hatano, R. (2015). Estimating sediment and particulate organic nitrogen and particulate organic phosphorous yields from a volcanic watershed characterized by forest and agriculture using SWAT model. Ann. Limnol. - Int. J. Limnol. 51, 23-35.

Wang, G., Wente, S., Gertner, G.Z., and Anderson, A.B. (2002). Improvement in mapping vegetation cover factor for the universal soil loss equation by geostatistical methods with Landsat Thematic Mapper images. Int. J. Remote Sens. 23, 3649-3667.

Wang, G., Gertner, G., Fang, S., and Anderson, A.B. (2003). Mapping multiple variables for predicting soil loss by geostatistical methods with TM images and a slope map. Photogramm. Eng. Remote Sens. 69, 889-898.

Westerberg, L.-O., and Christiansson, C. (1998). Landslides in East African highlands. Slope instability and its interrelation with landscape characteristics and land use. Adv. GeoEcology 31, 317325.

Whitworth, M.C.Z., Giles, D.P., and Murphy, W. (2005). Airborne remote sensing for landslide hazard assessment: a case study on the Jurassic escarpment slopes of Worcestershire, UK. Q. J. Eng. Geol. Hydrogeol. 38, 285-300.

$\mathrm{Xu}, \mathrm{H}$. (2006). Modification of normalised difference water index (NDWI) to enhance open water features in remotely sensed imagery. Int. J. Remote Sens. 27, 3025-3033.

Yang, X. (2014). Deriving RUSLE cover factor from time-series fractional vegetation cover for hillslope erosion modelling in New South Wales. Soil Res. 52, 253.

Zhang, L., and Zhong, Y. (2009). Analysis of Hyperspectral Remote Sensing Images. In Geospatial Technology for Earth Observation, D. Li, J. Shan, and J. Gong, eds. (Boston, MA: Springer US), pp. 235-269.

Zhang, X., Shang, K., Cen, Y., Shuai, T., and Sun, Y. (2014). Estimating ecological indicators of karst rocky desertification by linear spectral unmixing method. Int. J. Appl. Earth Obs. Geoinformation 31, 86-94. 